\title{
Discourses on Development and the Muslim World
}

\author{
Farouk Abdullah Alwyni \\ Faculty of Economics and Business \\ Perbanas Institute, Jakarta \\ Indonesia \\ Muhammad Syukri Salleh \\ Centre for Islamic Development Management Studies (ISDEV) \\ Universiti Sains Malaysia, Penang \\ Malaysia
}

\begin{abstract}
Development is one important issue facing most Muslim countries today. Although there are different stages of development, all of the Muslim countries at this time are considered as developing countries as per the United Nations $(U N)$ country classification. However, it is important to note here that actually the discourses on development used to differentiate countries between developing and developed have been debated for a while. One critical discourse contends that even those countries considered developed are actually still developing, considering that all countries are basically reacting and evolving to cope with different challenges in their own respective economies. In view of the above, this paper attempts to assess discourses related to development in developed countries as well as developing ones (including Muslim countries). This paper will also review the present state of the Muslim World that is relatively lagging behind, and what should be done about that. The research methodology applied will be based on literature review related to discourses on development, and some empirical evidence related to those discourses. The paper shows that actually each and every country has its own unique approach to develop, and there will not be a one size fits all development discourse for many different countries in the world. Learning from the history, Islam, as a belief system, made a significant role in transforming the early Muslims from backward nations to the most developed ones at that time. In addition, there has been an endless quest in developed countries themselves for more social justice and for more meaning of life. Therefore, the paper argues that formulating Islamic-based development discourses will benefit not only the Muslim world (to make it better their present state of development) but also a global community (to make a more just and humane world).
\end{abstract}

Keywords: Discourses on development, developing countries, developed countries, Muslim world, Islamic-based development.

\section{Introduction}

Development is one of major issues facing the Muslim countries. Most Muslim countries, if not all, are considered to be lagging behind compared to Western countries in Europe and North America, East Asia countries such as Japan, South Korea, Singapore, and Hong Kong, and Australia and New Zealand. But what are the indicators that built up such a consideration?

Todaro (2011:14) observes that one dominant indicator that determines the consideration for the different levels of development is per capita growth (and income). For instance, he states as follows:"development was until recently nearly always seen as an economic phenomenon in which rapid gains in overall and per capita GNI growth would either "trickle down" to the masses in the form of jobs and other economic opportunities or create the necessary conditions for the wider distribution of the economic and social benefits of growth."

However, such an opinion is not a consensual one. Other scholars such as Schafer, Haslam, \& Beaudet, (2009:10) acknowledge that "... it remains difficult to concisely define what 'development' is and how exactly to measure it." They argue that: "Different approaches to defining 'development' reveal different aspects of the problem: the need to distinguish between levels of industrialization, the need to consider different segments of the population, the need to look specifically at poverty, and the need to consider development as an 'ideal' or aspiration for betterment" (Schafer, Haslam, \& Beaudet, 2009:10).

It is important also here to state that there are also a number of critiques on the term of 'development'. Rist (2010) for example is one of those critics. He (2010:23) defines development as follows: 
"the essence of 'development' is the general transformation and destruction of the natural environment and of social relations in order to increase the production of commodities (goods and services) geared, by means of market exchange, to effective demand. This formulation may appear scandalous compared with the wishful thinking that usually characterises definitions of 'development'. But I contend that it truly reflects the actual process observable when a country or a region is 'developing'."

In view of the above, it can be observed that discourses on development vary even within the conventional Western paradigm itself, let alone if we expand the discourses by taking into consideration of Islamic-based discourses. In the next sections, we will review discourses on development and how they affect development policies in so called developed and developing countries (including Muslim countries) alike and the results created.

\section{Discourses on Development}

In reviewing discourses on development, the paper starts from the period where the so-called developed world today was basically still developing. This was the time when European countries were also still working in developing their nation states. So, this is called a national development discourse. The second discourse was the period starting after 1945, the period where many countries just freed themselves from or still under the rule of Western colonialism, and where there were efforts in the so-called developing countries to develop themselves. The third discourse was discourses critical to the concept of development itself, questioning the legitimacy of the Eurocentric approach of development. Lastly, the section will also review Islamic-based development discourse, which somehow could become a productive result of post-development discourse since this discourse does not only offer critiques but also give alternative approaches.

\section{National Development Discourse}

This development discourse basically started after Europe ended its 30 years' war, known as the peace of Westphalia in 1648 (Hettne, 2005:30). This is the era that came to be known as the 'Westphalian era.' This Westphalian era then created the emergence of sovereign states, later also known as nation-states. According to Hettne (2001), the Westphalian era was an era of state formation and mercantilist nation-building, during which 'development' became a 'national interest', even an imperative for state survival. Here, each nation state in Europe competed to develop itself to be a strong state.

The salient feature of the development discourse during this period is more on security of a nation in dealing with external enemies. Therefore, each and every nation needs to build its military capability through industrialization. The industrial revolution taking place in England between 1760 and 1840 somehow gave realisation to countries in Europe that they needed to follow the path of England to industrialise. Hettne (2001) notes that 'development' in an anarchical system implied a strengthening of the material base of the state through industrialization, a process remarkably similar from one country to another, and reinforced by the security interests of the ruling elite.

It is interesting to note here that actually the development discourse during this period is best reflected in the work of Friedrich List (Jolly, 2004:25-26), not Adam Smith, since the development process during this time is more statedriven. List believes on the need to develop productive power of a nation through manufacturing, and he saw also the merit of protecting local industries until they could compete with foreign products. List saw that greater gains in term of the capacity to produce cheaper manufactured goods internally (compared to the needs to import) and to create industrial independence in case of war would justify a loss under protection (Jolly, 2004:25).

The constant threat of war somehow boosted industrialisation efforts of European countries at that time, a sense of 'industrialise or perish' as Hettne (2001:25) put it. Hettne (2001:25) shows in the following how the issue of security contributed to development through industrialisation and at the end contributed also to the colonialism:

'Since 'power' was defined in terms of military capacity, the industrialisation process was, for security reasons, repeated from one country to another. Similarities in the pattern of economic development did not reveal inherent tendencies in history towards 'modernity' but rather security imperatives for the emerging states, making industrialisation necessary simply for military reasons. To this should be added that the 'expansion of Europe', which also became an 'expansion of international society' (Bull and Watson, 1984), was a competitive process, involving a number of core states struggling for hegemony, with crucial repercussions in the rest of the world, subsequently divided into colonial empires. In a global perspective, the First Discourse thus coincides with the era of colonialism in Asia and Africa and neocolonialism in Latin America."

Discourse on development that affected Europe basically also affected the development imperative in the Soviet Union. Realizing the need to catch up with competing forces of Europe and the United States, Soviet leaders in the early era such as Lenin and Stalin stressed the need to develop as a matter of survival for the new state i.e. Soviet Union as shown in their own words as follows (Hettne, 2001:25-26): 
"Similarly, the Soviet state, ideologically a product of the second movement, was consolidated by war against both internal and external enemies. During the October Revolution Lenin had said: 'Either perish or overtake and outstrip the advanced capitalist countries'. In the early 1930s Stalin echoed: 'We are fifty or a hundred years behind the advanced countries. We must make good this distance in ten years. Either we do it or they crush us' (Holloway, 1981:9). This was the modernisation imperative as it appeared to the Russian revolutionaries and it led to an extreme variant of the modern project."

This national development discourse that somehow contributed to the development of European countries was actually different with present recommendations given by the World Bank and the International Monetary Fund (IMF) to the socalled underdeveloped countries (Hettne, 2005:31). Furthermore, List's approach mentioned above on protectionism and support for 'infant industries' in order to catch up with the strong powers earned him the title of the 'father' of development economics (Hettne, 2005:31).

In fact, the United States (US) itself according to Jolly (2004:25) was the birthplace of the protection of infant industries. Alexander Hamilton, the first secretary of the treasury in the government of George Washington who believed that manufacturing was critical for economic development and a strong economy, designed policies - adopted by the US - that protected home market until American industry was strong enough to deal with the onslaught of the (already) industrialising European nations. Jolly (2004:26) further notes that,

"In addition to protective tariffs, Hamilton argued in favor of government investments in infrastructure, unification of thirteen former colonies into a single market without internal tariffs, and establishment of a unified creditworthy financial system. The U.S. not only followed these policies for a century and a half but also remained the world's most heavily protected economy until World War II."

\section{Post-1945 Development Discourse}

Post-1945 development discourse basically spanned a long period of time till the emergence of post-development discourse in 1990s. However, the emergence of post-development discourse is not in itself mark the end of evolving development discourse. Development discourse keeps adjusting itself to the new reality of the changing world, trying to remain relevant in offerings thoughts to the majority parts of the world considered not developed, or at least not fully developed yet. In fact, some even argues, which will be discussed later in this paper that there is no such thing differentiation between developing and developed world since basically all countries are still developing, considering that all countries still need to deal and address their own internal economic, socio, and political, in short development challenges (Miles, 2004:8; Laffer, 2004:149).

The issues related to post-development discourse will be reviewed soon after the discussion on this section. Using Hettne's (2005:30) stages and terms of development discourses, this post-1945 development discourse is put as the 'second discourse' and called 'the geopolitics of poverty.' During this period, the world was divided into two competing political and socio-economic systems, the United States and the Soviet Union, both exerted efforts in spreading their versions of development and modernisation. This period was also called the period of post-colonial eras where many countries in Asia and Africa just declared their independences, and Europe reconstructed their countries after the World War II.

According to one study (Schafer, Haslam, \& Beaudet, 2009:5), this period witnessed the use of 'underdeveloped areas' as a new term in development first mentioned in a speech by Harry Truman, President of the United States of America, in his 1949 inaugural address. In this speech, Truman implied that criteria for those underdeveloped areas were inadequate food, disease, primitive economic life, and poverty whereas those developed areas were scientific advancement and industrial progress. Here, Truman also stressed the threat to the so-called 'free world' if it failed to address the issues facing underdeveloped areas, this somehow would become the main rationale for development aid in the Cold War climate (Hettne, 2005:33). The excerpts of this speech are as follows:

"We must embark on a bold new program for making the benefits of our scientific advances and industrial progress available for the improvement and growth of underdeveloped areas. More than half of the people of the world is living in conditions approaching misery. Their food is inadequate, they are victims of disease. Their economic life is primitive and stagnant. Their poverty is handicapped and a threat to both to them and more prosperous areas. For the first time in history, humanity possesses the knowledge and the skill to relieve the suffering of these people ... our imponderable resources in the technical knowledge are constantly growing and are inexhaustible. ... The old imperialismexploitation for foreign profit-has no place in our plans" (Schafer, Haslam, \& Beaudet, 2009:5). 
However, it is important to note here that in order not to distract the country classification in this paper, the term 'underdeveloped areas' mentioned above will not be used further. Rather, this paper will just use the term developing countries for low- and middle-income countries and all countries not included in the high-income Organization for Economic Cooperation \& Development (OECD) member countries ${ }^{1}$ (Todaro, 2011:41).

However, it needs to be borne in mind that this classification actually is not very accurate either considering there are wide economic differences between low income countries in sub-Saharan Africa and upper-middle-income countries in East Asia and Latin America. Nevertheless, this classification is still useful to keep the simplicity in differentiating those high-income OECD member countries from 'majority world' countries (Schafer, Haslam, \& Beaudet, 2009, p. 8; Todaro. 2011:41).

Going back to the discussion on post-1945 development discourse, there are a number of main theories that shaped the discourses during this period. The outlines of these theories are put in Table 1. Each one of them is discussed briefly below.

Table 1: Theories of development

\begin{tabular}{|c|c|c|c|c|}
\hline $\begin{array}{l}\text { Theory/ } \\
\text { Theme }\end{array}$ & $\begin{array}{l}\text { Emergence/ } \\
\text { Dominance }\end{array}$ & $\begin{array}{l}\text { Discipline/ } \\
\text { Tradition }\end{array}$ & The Problem & The Solution \\
\hline $\begin{array}{l}\text { Development } \\
\text { economics }\end{array}$ & $1950 \mathrm{~s}$ & Keynesian economics & $\begin{array}{l}\text { Low-level } \\
\text { equilibrium }\end{array}$ & $\begin{array}{l}\text { Injection of capital and management } \\
\text { of disequilibria to put economy on a } \\
\text { growth path to high-level equilibrium }\end{array}$ \\
\hline $\begin{array}{l}\text { Modernization } \\
\text { theory }\end{array}$ & Late 1950s & $\begin{array}{l}\text { Weberian/ } \\
\text { Parsonian sociology }\end{array}$ & Traditional society & $\begin{array}{l}\text { Modernization through diffusion of } \\
\text { modern values and institutions }\end{array}$ \\
\hline $\begin{array}{l}\text { Dependency } \\
\text { theory }\end{array}$ & 1960s & $\begin{array}{l}\text { Prebisch, Economic } \\
\text { Commission for Latin } \\
\text { America, Marxism }\end{array}$ & $\begin{array}{l}\text { Dependency within } \\
\text { a world capitalist } \\
\text { system }\end{array}$ & $\begin{array}{l}\text { Delinking, fully, or partially, or } \\
\text { socialism }\end{array}$ \\
\hline Neo-liberalism & $1970 \mathrm{~s}$ & $\begin{array}{l}\text { Neo-classical } \\
\text { marginalist economics, } \\
\text { Austrian economics }\end{array}$ & State intervention & Free markets \\
\hline $\begin{array}{l}\text { Developmental } \\
\text { states }\end{array}$ & $1970 \mathrm{~s}$ & $\begin{array}{l}\text { Listian nation 'neo- } \\
\text { mercantilist' political } \\
\text { economy }\end{array}$ & Free markets & $\begin{array}{l}\text { State management of the economy to } \\
\text { increase productivity, equality, and } \\
\text { technological upgrading }\end{array}$ \\
\hline
\end{tabular}

Source: Desai, 2009:53.

\section{Development economics}

This theory basically stressed the importance of government's role in development. Provision of health, education, instituting unemployment insurance and public pensions are the areas where the State needs to play a larger role, even to the extent of owning key industries. Development economics emerged after the Second World War and saw the Great Depression as the symptom of capitalist crises. Like Keynesian, development economics used the tools of fiscal and monetary 'macroeconomic' policies to boost demand in the crises times in order to restore equilibrium in labors and capitals.

\section{Modernisation theory}

Walter Rostow's The Stages of Economic Growth was basically the foundation of modernisation theory. Rostow (1960), using the economic history of England and Western Europe, depicted the stages of economic changes from 'traditional' societies to modern 'high mass consumption' societies. In between these two states, societies would pass through three states, which were 'preconditions for take-off', 'take-off', and the 'drive to maturity.' High mass consumption society was described as the state when the average incomes were high, exceeding basic needs. This was the time also when welfare states could be instituted and military could be strengthened. It was assumed that this Rostow's stages of growth was the model, the end state, for the developing countries to follow the path of developed countries.

Expanding from Rostow's theory, modernisation theory incorporated sociology and political science. It projected that in order to develop, the ex-colonial 'traditional' countries needed to adopt formerly imperial 'modern' values and institutions in addition to capital injection.

\footnotetext{
${ }^{1}$ The high income OECD member countries consist of countries in Western Europe, North America, Japan, Australia, New Zealand, and South Korea. 
This theory to a large extent equated that to develop and modernise, countries needed also to westernize, creating close contacts economically, socially, politically, and culturally with former colonial masters would be desirable for development.

\section{Dependency theory}

Different with the two previous theories above, dependency theory connected development problems in developing countries with the historical past of colonialism and imperialism. This theory saw that imperialism was the product of capitalism. Dependency theory argued that developing countries would not be able to develop under capitalism and the solution laid in socialism. This theory originated with two papers published in 1949, one by Hans Singer and the other one by Raul Prebisch (Engel, 2010:7-8). They saw the worsening of the terms of trade of developing countries relative to developed countries. This was due to the facts that the prices of manufactured goods of developed countries would tend to go up faster than the prices of primary commodities of developing countries. In addition, demand for manufactured goods tended to rise with income, but this was not the case for primary commodities. Consequently, developing countries would go deeper into poverty if they depended on primary products.

Dependency theory, with its diverse set of theories, observed that the world economy was divided between an advanced industrial 'core' and a largely agricultural 'periphery.' Other work related to dependency theory was the 'world system' theory. This theory saw that "the capitalist world-economy was the product of a centuries-long expansion of European capitalism dating back to the fifteenth century" (Desai, 2009:58). Dependency theory and its variants mostly focused on issues related to imperialist subjection and exploitation. This theory was known as part of leftist tradition of development economics and has its root in Marxist political economy (Engel, 2010:7).

\section{Neo-liberalism}

Neo-liberalism is basically a reincarnation of neo-classical economy. The neo-classical assumption that individuals are rational and they maximize their utility or benefits is also the foundation of neo-liberals' thoughts, as in line also with classical economics. Neo-liberals view that giving full freedom to individuals to participate in the market and gain the full benefits of it would create productive economies (Engel, 2010:13). Neo-classical and neo-liberal share the same argument on the benefit of free trade as opposed to the loss from protection (Engel, 2010:14).

Neo-liberalism played an important role in shaping policies in both developed and developing countries in 1970s 1980s. Neo-liberalism "favored supply side macroeconomic policies, rational, expectation theories, and the privatisation of public corporation" in the developed countries, and "it called for freer markets and the dismantling of public ownership, statist planning, and government regulation of economic activities" in developing countries (Todaro \& Smith, 2011:126-127). Policy prescriptions and/or development strategy associated with neo-liberalism was also known as the Washington Consensus, due to the facts that it was agreed in Washington between the US Treasury, the World Bank, and the IMF (Engel, 2010:13, 16-17).

Neo-liberalism/neo-classical argued that the reasons of the underdevelopment in developing countries are due to "the heavy hand of the state and the corruption, inefficiency, and lack of economic incentives that permeate the economies of developing nations" (Todaro \& Smith, 2011:127). Therefore, in order to stimulate the economy and develop, or to allow the "magic of the marketplace" and the "invisible hands" in term of classical economics, developing countries need to promote free markets and laissez faire economics, privatise state-owned enterprises, promote free trade and export expansion, welcome investors from developed countries, and eliminate the plethora of government regulations and price distortions in factor, product, and financial markets (Todaro \& Smith, 2011:127).

The critics of neo-liberalism contended that neo-liberalism in developed countries "resulted in unprecedented rates of unemployment, poverty, inequality and de-industrialisation, ending the 'golden age' of the Keynesian welfare state" (Desai, 2009:61). The implication of neo-liberal policies in developing countries, according to its critics, is far worse, it "entailed comprehensive state intervention to re-engineer whole economies in favor of private capital -foreign more than domestic, financial more than productive", which contradicted the philosophy of neo-liberalism itself that is against the state intervention (Desai, 2009:61).

Furthermore, with the growing influence of neo-liberal thoughts in international institutions such as the International Monetary Fund (IMF) and the World Bank (WB), these institutions used neo-liberal-inspired policies called structural adjustment programs (SAPs) in dealing with developing countries having balance of payment difficulties and/or in need of development financing (Desai, 2009:61). On SAP, critics went further as follows (Desai, 2009:61):

“... For the next two decades, countries under SAPs, a majority of Third World countries, were forced to expand exports of mostly primary commodities and low value-added industrial products to pay back the debt.... Contrary to all notions of development, neo-liberalism engineered a massive transfer of capital from the Third World to the First. 
The series of 'lost decade' of development, with negative growth rates in many Third World countries, are often blamed on poor government policies. However, with state spending restricted and interventionism ruled out, no attempt to break out of the production of low value-added products -in effect no development-could even be contemplated...

Neo-liberalism's anti-state and pro-market dogma proved the end of 'development' as originally conceived: with the nation state as its chief agent and industrialisation its key components.... Amid all this, development, industrialisation, and 'catching up' to First World levels of prosperity remained a distant dream for of the Third World."

\section{Developmental states}

In contrast to neo-liberalism approach, developmental state approach saw that the market was not perfect, there was always possibility of a market failure in the development process. Therefore, there is a need for the state to play a constructive role in the development. According to Caldentey (2008:28),

"The term developmental state refers to a state that intervenes and guides the direction and pace of economic development. The developmental state is mainly associated with the type of economic policies followed by East Asian governments in the second half of the twentieth century and, in particular, with the post-World War II Japanese economic model."

Apart from Japan, the development success of Hong Kong, Singapore, South Korea, and Taiwan that experienced rapid economic growth and socioeconomic transformation made international development institution like World Bank, development practitioners, and academics realize the importance of state in the development process (Fritz \& Menocal, 2006:2-4).

The experience of East Asian countries, according to Fritz \& Menocal (2006:3), "served to highlight the fact that even market-based economies require functioning, capable states in order to operate and grow." Fritz \& Menocal (2006:3) continues that "states came to be expected (once again) to meet the basic needs of the population and deliver essential social services."

Interestingly, the above awareness of the importance of functioning and capable state in guiding the social and economic development process came at around the same time with the rediscovery of the role of institutions in the field of economics, known as New Institutional Economics (NIE) (Fritz \& Menocal, 2006:3; Engel, 2010:18). NIE basically argued that functioning institutions are critical requirements and determinants of growth, as opposed to the earlier neoclassical thinking that saw institutions as a by-product of economic growth (Fritz \& Menocal, 2006:3).

Here, institutions are considered as the key explanatory variable that determine why some countries have developed and some others have not. Institutions are expected to "provide dependable property rights, manage conflict, maintain law and order, and align economic incentives with social costs and benefits" (Fritz \& Menocal, 2006:4). This realization on the critical role played by institutions in ensuring social and economic development success also made the World Bank broadened its developmental role to include fighting corruption, improving transparency, creating accountability in governance, strengthening judicial system, and modernizing financial sectors (Uvin, 2010:167).

\section{Post-Development Discourse}

As mentioned earlier in the previous section, the post-development discourse is actually part of the discourses on development. It started ascending within development discourses in 1990s. Desai (2009:66) notes that three factors paved the way for the emergence of post-development discourse, as follows. "... the crisis of post-1945 development theories; the perceived failure of development practices informed by dominant theories of development (specifically modernization and neo-liberalism); and the rise of post-modern thought in the academy."

On the last point above, it was argued that "the rise of post-modern and post-structuralist debates in the academy greatly contributed to the emergence of the post development perspective" (Desai, 2009:69). On how post-modern and post-structuralist thought contributed to post-development discourse was the critical thoughts on issues related to among others colonial representation and knowledge. Post-development thinkers, inspired by post-modern thought, reviewed critically development theories against the backdrop of the conception of the white man's burden that legitimized European colonialism (Desai, 2009:70). This conception justified the colonialism as a civilizing mission of colonial authorities that would bring benefit to the people considered savage and backward. Thus, post-development thinkers saw development theories particularly modernization and neo-liberalism as the products of colonial European ideas that only saw European perspective as universal truth. Similarly, post-development thinkers also criticized approaches that wanted to universalize knowledge without considering different social constructions and historical settings in different societies, which make knowledge not neutral (Desai, 2009:69). 
Moreover, post-development thinkers also considered that the so-called 'developed countries' actually are not a good model to be emulated also, as one post-development thinker (Rist, 2010:24) put it in the following, "....in a 'developed' country, human beings are also turned into 'resources' and are expected to know how to sell themselves to potential employers. Prostitution may be officially condemned, but it has become the common lot: everyone is for sale."

Rist (2010:24) continues further in criticizing development in regard to its impacts as follows: “... one should add an inventory of its devastating side effects, not only on the environment and the precarious equilibrium of the biosphere, or on the conservation of natural resources (forests, arable land, fish stocks) which are overexploited, but above all on the continuous impoverishment of millions of people. As Jeremy Seabrook (1998) has it, poverty is not a form of 'illness' that demonstrates the malfunctioning of capitalism and can be 'cured'. On the contrary, poverty is proof of the 'good health' of the capitalist system: it is the spur that stimulates new efforts and new forms of accumulation. To put it differently, economic growth - widely hailed as a prerequisite to prosperity - takes place only at the expense of either the environment or human beings."

According to Ziai (2007:3-5), there were three major thoughts representing post-development discourses. First, the thoughts that foresaw that the age of development was coming to an end. The proponents of these thoughts reasoned as follows:"the industrial model of society could no longer be conceived as ahead in the evolutionary scale in the light of the ecological predicament, that the project of development which had been an instrument in the Cold War was bound to exhaust itself after 1989, that the development era had not led to a process of catching up for most of the 'developing world' but to a widening gap between rich and poor countries, and finally that 'development' was a 'misconceived enterprise' in that it implicitly aimed at eliminating cultural diversity through the universalizing of Western institutions" (Ziai, 2007:4).

Secondly, thought that gave alternatives to development. An approach that shares "an interest in local culture and knowledge; a critical stance towards established scientific discourses; and the defense and promotion of localized, pluralistic grassroots movements" (Ziai, 2007:4). This type of post-development thought claimed that: "new social structures were in the making based on different conceptions of the economy (solidarity and reciprocity instead of homo-economicus and the world market), of politics (direct democracy instead of centralized authorities), and of knowledge (traditional knowledge systems instead of modern science). Frequently, 'traditional' and 'modern' elements would be mixed or "hybridized"' (Ziai, 2007:5).

The third major thought was that saw development as a misapplied response to the needs and aspirations of the people in developing countries. The proponents of this post development school contended that development: "was an ideology that was born and refined in the North, mainly to meet the needs of the dominant powers in search of a more 'appropriate' tool for their economic and geopolitical expansion ... the ideology helped a dying and obsolete colonialism to transform itself into an aggressive - even sometimes an attractive - instrument able to recapture new ground. ... The hidden - yet clear - message that every development project has carried to the people at the grassroots has been that their traditional modes of living, thinking and doing have doomed them to a subhuman condition" (Ziai, 2007:5).

\section{Islamic-based Development Discourse}

We have seen above a number of discourses on development from the early era of European development till the present times. Although there are different discourses in approaching development issues, but all of the above basically approach development in term of material and physical development, and at best plus social, cultural, and environmental approach as in the case of post-development discourse. However, all discourses are only looking at development issues from the worldly perspective. They care more only about the welfare of the people here in this world.

Nevertheless, when we talk about Islamic-based development discourse, we need to take the religious dimension or the belief system of Islam into development (Alwyni, 2011:27-28). Therefore, we will need to subscribe to the religious worldview of Islam itself. Thus, we will need to have a new approach in looking at development. In Islam, the world that we live in today is considered as a temporal world, it will have an end sooner or later. It is even considered as much shorter world than the world to come in the Hereafter. According to the Islamic belief system: "a person could end up having a much better life in the hereafter or much worse, it is about ending up in paradise or hell. Whatever we do in this world good or bad will be recorded, and have consequences for our life in the next world. So, basically doing a lot of good for others in this world is for his or her own interest in the hereafter since they will not go un-recorded and/or un-rewarded, or unpunished otherwise (for doing bad)" (Alwyni, 2011:27). In view of the above, we will need to approach development in a more comprehensive manner, not only about the welfare and/or the success in this world, but also in the Hereafter. Within this context, we will study briefly thoughts of three Islamic scholars on Islamic-related concept of development. These are Ahmad (1981), Salleh (2003), and Chapra (2008). 
First, we start from Ahmad. Ahmad (1981:178) contended that the philosophical foundations of the Islamic approach to development are Tawhìd (God's unity and sovereignty), Rubübiyyah (divine arrangements for nourishment, sustenance and directing things towards their perfection), Khiläfah (man's role as God's vicegerent on earth), and Tazkiyah (purification plus growth).

From Tazkiyah, according to Ahmad (1981:179), the Islamic concept of development would lead to falāh, which is prosperity in this world and the Hereafter.

Ahmad (1981:179-181) then argued that based on the foundational principles above the essential features of Islamic concept of development are (i) having a comprehensive character and include moral, spiritual, and material aspects; (ii) Man, and his physical and socio-cultural environment, will be the focus of the development effort and the heart of development process; (iii) stressing more on the multi-dimensional activity of economic development; (iv) quantitative and qualitative aspects are equally important; (v) Emphasizing optimal utilization of resources for the benefits of man and his physical environment, and their equitable use and distribution and promotion of all human relationships on the basis of Right and Justice.

Moving a bit further, Ahmad (1981:180-182) formulated the following general goals of development policy within the above Islamic concept: (i) Human resource development should be the first objective, this would include the development of correct attitudes and aspirations, character and personality, knowledge and skills, research, responsible \& creative participation of all people in development activities, and the spirit of sharing the fruits of development; (ii) Expansion of useful production, those things that are essential and useful such as food and basic items of necessity (including construction material for building houses and roads and basic raw materials); defence requirements; and basic capital goods; (iii) improvement of the quality of life, this would prioritize employment creation, social security system, and equitable distribution of income and wealth; (iv) Balanced development of different regions within a country, avoiding a dual society; (v) New technology, that is evolution of indigenous technology, suited to the conditions, needs, and aspirations of the Muslim countries; (vi) Reduction of national dependency on the outside world and greater integration within the Muslim world.

The second scholar, Salleh (2003:13-18; 2013:8-12) believed that the Islamic concept of development should at least have seven principles. First, Islamic worldview (Tasawwur) as the mould of Islamic development. Salleh (2013:8) contended that Islamic worldview "refers to the real picture of Islam in one's mind and blended intimately within oneself, establishing a form of understanding about Islam and subsequently influencing one's thought and behavior." The rise of culture and civilization of early Muslims cannot be separated from this worldview (Salleh, 2013:8).

Secondly, man as actor of Islamic development. Salleh (2013:8) argued that from an Islamic perspective man is beyond the mere concept of homo-economicus known in many economic theories, particularly in classical economics. Rather, Salleh contended using the Qur'anic text that man is given a mandate by God to be His servant and vicegerent ('abdAllah and khalifatullah respectively) on the earth (Salleh, 2013:8). Here, man has a higher status than just become an economic man, a person who only looks after his own self-interest, or a pseudo-human being.

Thirdly, world of Malakut (the world before the present world), present World and the World Hereafter as the timescale of Islamic development. Salleh wrote that the concept of Islamic development started from the world of malakut when the man-God contract was established as stated in the Qur'an, continue to the present world, and the final one will be in the Hereafter (al-akhirah), the place where the real success (or failure) will be determined (2013:9).

Fourthly, obligatory knowledge (fard ain) as the framework of Islamic development. Salleh explained that this obligatory knowledge is divided into three disciplines, viz. Tawhid, Fiqh, and Tasawwuf (Salleh, 2003, p. 41-45; Salleh, 2013, p. 9-10). Tawhid is related to Islamic belief (aqidah), this to ensure that any development efforts should be done for the sake of God. Fiqh is related to rules and regulations (Shari'ah), it is to ensure that development should be done within the rules and regulations of Islam. Lastly, Tasawwuf, it is related to good behavior (akhlaq), differentiating between good and bad behaviors, it is to ensure that development endeavors should be done with Islamic values shaping good characters such as honesty, trustworthiness, ethics \& morality.

Fifthly, Ibadah (the worship of God) as the methodology of Islamic development. Salleh saw that in Islam worshipping God is an obligation for all Muslims as this is the essence of their life in this world (Salleh, 2013:10). Salleh (2003:48; 2013:10) stated that according to Islam there are three types of worship. First is the basic worship outlined in the five pillars of Islam (praying, fasting, paying zakat, and performing hajj). Second is the commendable practices of worship such as supplementary prayers and fasting, gifts (sadaqah), performing umrah, remembrance of God (zikr), et cetera. Third is the general worship, which is realizing social obligations (fard kifayah) like marriage, social, economic, and political activities, and other things related to other fellow beings and environment (hablum-minannas) within the Shari'ah guidelines. 
In Salleh's perspective (2003:51-42; 2013:10), these three types of worships should be done correctly in order to achieve an Islamic concept of development that will include spiritual, physical, and material development. The first and two worships are for spiritual development whereas the third worship is for physical and material development.

Sixthly, natural resources as the means of Islamic development. In this principle, Salleh $(2003: 70-77 ; 2013: 12)$ used Islamic concepts in challenging a conventional development perspective on the scarcity of resources.

Salleh (2013:12) contended that in Islam "resources are actually sufficient for all, it not abundant, and one is actually able to limit his wants." Salleh used the Islamic concept of rizq (provision from God) and barakah (blessing of God) in arguing about the sufficiency of resources for all. According to Salleh, the most important thing is to control the level of desire of man. Salleh uses this approach in also challenging the conventional development concept on the unlimited wants. Salleh (2013:12) contended that from an Islamic perspective "the wants could actually be limited by raising the level of desire (nafs) to higher ones (mutmainnah, radhiyah, and kamilah). In consequence, the resources could therefore be exploited according to the needs rather than to the wants. The desire is indeed the one that stimulates the wants".

Finally, the seventh principle is mardhatillah as the ultimate aim of Islamic development. Here, Salleh (2013:12) states the following: " $\ldots$ the aim of the Islamic development is not just to accomplish success in this present world but also, and in fact more important, is the success in the Hereafter. This could be achieved only with the pleasure of God (mardhatillah). Since only with the accomplishment of the pleasure of God one could attain the success both in this present world and in the Hereafter, the ultimate aim of the Islamic development is therefore the pleasure of God, the mardhatillah".

The third and final scholar on Islamic development discourse that we will study is Chapra. Chapra (2008:1) argues that the objectives of development in Islam are related to the objective for which Islam was revealed through the Prophet Muhammad [PBUH], that is as a blessing for all universe [Qur'an, 21:107], Rahmatan Lil' Alamin. One important way to realize this goal, according Chapra (2008:1), is to bring about faläh or "real well-being of all the people living on earth, irrespective of their race, colour, age, sex or nationality."

Chapra (2008:1) states that the word falāh and its derivatives was used 40 times in the Qur'ān. Other word, fawz, which is a synonym of fala h, was used 29 times along with its derivatives. The importance of falah in Islamic worldview could also be seen on how this word is part of call for prayers (Adhan) five times a day. Chapra (2008:2) contends that the fundamental difference between the Islamic concept and the conventional one in looking at the welfare, a primary thing that want to be achieved by development, is that Islam does not see welfare only from a material perspective, but also from a spiritual perspective, and it is related also to the achievement of non-material needs. These non-material needs are among others - most important ones - mental peace and happiness, where the need to achieve these will require the fulfillment of other needs such as justice and human brotherhood, which will demand equal treatment among individuals where every person will need to be treated with dignity and respect, and that the fruits of development could be shared equitably (Chapra, 2008:2-3).

In addition to the above, other important non-material needs related to the fulfillment of sustainable well-being are among others: spiritual, moral upliftment, security of life, property and honor, individual freedom, moral as well as material education, marriage and proper upbringing of children, family and social solidarity, and minimization of crime and tension'(Chapra, 2008:3).

In approaching the above mentioned needs Chapra (2008:4) basically uses the concept of Maqasid al-Shari'ah (goals of the Shari'ah). Imam al-Ghazali, a fifth century great Islamic scholar, classifies Maqasid into five categories as follows (quoted from Chapra, 2008:4):

"The very objective of the Shari' 'ah is to promote the well-being of the people, which lies in safeguarding their faith $(d \bar{i} n)$, their self (nafs), their intellect ('aql), their posterity (nasl), and their wealth $(m \bar{a} l)$. Whatever ensures the safeguard of these five serves public interest and is desirable, and whatever hurts them is against public interest and its removal is desirable."

Chapra's approach to the Islamic concept of development actually has also been reviewed by Salleh (2010:93-101). In this book review, Salleh shows some differences between his approach and Chapra's. But, it is not the purpose of this paper to discuss that further.

\section{The State of Development of the Muslim World}

\section{What is the Muslim World?}

The Muslim world basically consists of 57 member countries of Organization of Islamic Cooperation (OIC), formerly known as the Organization of the Islamic Conference. 
The member countries are spread in four continents from Asia, Africa, Europe, and America. According to its website (https://www.oic-oci.org/), the Organization is the collective voice of the Muslim world and ensuring to safeguard and protect the interest of the Muslim world in the spirit of promoting international peace and harmony among various people in the world.

Those countries joining the OIC are governments that have adopted Islam as the official state religion, or have Islam as their primary religion; or have a significant Muslim population, or have simply declared themselves an Islamic republic (Askari \& Rehman, 2013:322).

The largest member countries in term of the population, or those whose populations exceed 70 million, were Indonesia (261 million), Pakistan (189 million), Nigeria (187 million), Bangladesh (163 million), Egypt (93 million), Iran (80 million) and Turkey (79.6 million). These countries accounted for more than half of the member countries' total population (Islamic Development Bank, 2017:1).

\section{What is their State of Development?}

Based on the United Nations (UN) country classifications (UN, 2017, p. 153-154), except for the countries classified as economies in transition such as Albania, Azerbaijan, Kazakhstan, Kyrgyzstan, Tajikistan, Turkmenistan, and Uzbekistan, all of the OIC member countries are classified as developing economies. These countries classified as developing economies include also seven high income OIC member countries (as per World Bank [WB] \& UN Classification), which are Bahrain, Brunei, Kuwait, Oman, Qatar, Saudi Arabia, and the United Arab Emirates. Except Brunei, these six high income countries are also known as Gulf Cooperation Council (GCC) countries.

Turkey is the only OIC member country that is also a member country of Organization for Economic Cooperation \& Development (OECD), an intergovernmental economic organization grouping mostly countries considered to be high income and developed. However, even using the classification of OECD itself, Turkey is still considered as an emerging country, and not a developed country (OECD, n.d., para. 2). This is mainly due to the fact that the gross national income (GNI) per capita of Turkey is still classified as an upper middle income country (UN, 2017:156; WB, 2017:5).

Out of 57 OIC member countries, 25 are categorized as least developed member countries (LDMCs) (Islamic Development Bank [IDB], 2017: ix), known in the UN classification as least developed countries (UN, 2017:157). The top ten largest OIC economies (in US\$ billion) are Indonesia (932), Turkey (857), Saudi Arabia (640), Nigeria (406), Iran (377), UAE (371), Egypt (332), Malaysia (296), Pakistan (284), and Bangladesh (228). The first three largest economies (Indonesia, Turkey, and Saudi Arabia) are grouped in the Group of Twenty (G-20), an international forum for governments and central bank governors from 20 major economies. The Gross Domestic Product (GDP) of these largest OIC economies are ranked $16^{\text {th }}, 17^{\text {th }}$, and $20^{\text {th }}$ respectively among the G-20 countries.

Looking at the Human Development Index (HDI $)^{2}, 6$ OIC member countries are in the category of very high human development (Brunei, Kuwait, Oman, Qatar, Saudi Arabia, and the United Arab Emirates), 15 are in the high human development category (Albania, Algeria, Azerbaijan, Iran, Jordan, Kazakhstan, Lebanon, Libya, Malaysia, Maldives, Oman, Suriname, Tunisia, Turkey, and Uzbekistan), 12 are in the medium category (Bangladesh, Egypt, Gabon, Guyana, Indonesia, Iraq, Kyrgyz Republic, Morocco, Pakistan, Palestine, Tajikistan, and Turkmenistan), and 24 are in the low category (Afghanistan, Benin, Burkina Faso, Cameroon, Chad, Comoros, Côte d'Ivoire, Djibouti, Gambia, Guinea, Guinea-Bissau, Mali, Mauritania, Mozambique, Niger, Nigeria, Senegal, Sierra Leone, Sudan, Syria, Togo, Uganda, Yemen, and Somalia) (IDB, 2017, p. 10).

Relating to the performance of OIC member countries compared to other countries in the world, we will look at the survey of the economic development of OIC countries done by Askari \& Rehman (2013, p. 306-322). In term of the overall trends in human development, Askari \& Rehman (2013, p. 306) found that the HDI of OIC countries as a group was below the world average over thirty years period (1980-2011). Although six GCC countries performed above the world average, but they were still below the average of OECD countries over this thirty year period (Askari \& Rehman, 2013, p. 306).

On education \& health, similar pictures could also be seen. Using the U.N. Education Index, which measures the adult literacy rate (with a two-thirds weight) and the combined primary, secondary, and tertiary gross enrollment ratio (with a one-third weight), it was also found that the OIC countries performance was also below average (Askari \& Rehman, 2013:306-308).

\footnotetext{
${ }^{2}$ The HDI is a composite statistic of life expectancy (health), education, and living standards (income per capita) measuring the level of social and economic development of a country. The HDI is expressed as a value between 0 (minimum) and 1 (maximum) to see the position of one country compared to other countries (Askari \& Rehman, 2013:322; IDB, 2017:8). 144
} 
However, the same like the above, the GCC countries performed above the world average but were still below the OECD average (Askari \& Rehman, 2013:306). Using the U.H. Health Index, measured as the life expectancy at birth, the health conditions in the OIC countries were also below world standards (Askari \& Rehman, 2013:308).

On income level, using GNI per capita in terms of purchasing power parity in U.S. dollar (PPP\$), the same pattern like the above emerged again. Overall OIC incomes were well below the world average whereas the GCC countries were around the same with the highly developed countries of the world (Askari \& Rehman, 2013:308-309).

Over the last 30 years, OIC countries also did not perform well in reducing income disparity and poverty levels (Askari \& Rehman, 2013:309-310).

Finally, the same could be inferred also relating to environmental quality and sustainability. Askari \& Rehman argued that "The OIC countries clearly trail the world when it comes to environmental responsibilities" (2013:311).

\section{The Way Forward: Learning from History, Formulating and Applying Islamic-based Development}

Looking at the facts that based on commonly accepted development indicators there is a lot of things to do for the Muslim World, represented by the OIC countries, as an Ummah to improve its position among the nations of the world. Indeed, there is a variety of stages of development among the OIC countries. Some countries are among the high income countries whereas many others are among the low income countries, and in between there are some middle income countries. So, the challenges of development in each and every OIC country are certainly different. This in itself will require a specialized study in each country.

However, taking into consideration different challenges faced by each and every OIC country, they at least share Islam as a common social and cultural value. Looking back to the history of Islam, there was also a major change taking place in the Arabian Peninsula at that time between pre-Islam and post-Islam period. It was essentially the story on how the birth of Islam and the process coming after that making a major development in the region that subsequently created progress. The Arabs considered irrelevant before by two great powers, which might be considered as fully developed nations using the present term, the Roman and the Persian, suddenly, within relatively short period of time, became the new great power itself, putting an end to those two great powers. The Persians themselves finally accepted Islam, and made significant contribution to the rise of Islamic civilization. Many other nations that embraced Islam after that also in process contributed to the further rise of this civilization, which in process also transformed those nations became more civilized and developed.

As we have seen in the second section, discourse on development was an old concept dating back to the rise of Europe. Whatever the term at that time, development was conceived as a change process to make something better, to transform a nation into a strong and prosperous nation. Long war in Europe followed by the Westphalian era created an awareness for each sovereign state at that time to build a strong and developed state to face the external enemy. The case of Islam was something unique on how a religion, a belief system, could also transform a nation consisting of a scattered tribe of animists into a civilized nation. This was the process of how spiritual development could create a major material development. Although that material development was actually not the objective in itself, but it then came as a byproduct of that strong spiritual development that had a bigger objective, that was seeking the pleasure of God al-Mighty (mardhatillah). This was one principle of Islamic-based development envisioned by Salleh above (2013:12).

Whatever a variety in discourses on development, including the post-development discourse that became critical to the meaning of the development itself, perceived to be heavily influenced by the Western standards, there it seems to be one common denominator that will be widely accepted that development and progress that follows at the end is something that will deliver justice, mercy, well-being/prosperity, knowledge, and wisdom to a nation. Certainly, from the Islamic perspective, that development and progress has to make that nation and its people to be closer to God also, and the environment within it needs to be conducive enough for the prevailing of good Islamic virtues, ritually and socially. At the present, it has to be acknowledged that no single Muslim country has reached that level yet, not even those considered as high income countries.

Thus, the way forward, formulating Islamic-based development complete with its own indicators will be an important work to be done for the Muslim World so that they could set up their own standards on what it means to be a fully developed nation, agenda to follow, and steps to be done to apply and achieve that. We have seen through a number of discourses on development discussed above that there was no single approach that could fit well in all countries. Many countries in Asia, Africa, and Latin America even got stagnant, including Muslim countries, trying to adapt the development discourse that did not really fit well with their own set of values. The important role of values in development process in fact was also indicated in the new approach of development economics (Todaro \& Smith, 2011:12). 


\section{Conclusion}

Many discourses on Development today basically is defined more by material standards, by efforts to achieve material progress, whatever discourse is used. Although it has to be acknowledged also that over the time, the concept of development has evolved to be deeper that it was originally introduced. Discourse on development has now gone beyond an economic perspective, it is not only pre-occupied by the issue of the rise of income, but it also cares more toward social and environmental achievements. Rising income is indeed still one important indicator, but it is not everything.

It is realized now that before the income could raise, there were prerequisites need to be put in place for the economy to grow. Service-oriented bureaucracy, rule of law, and good governance are all now cited as prerequisites for economies to grow.

The emergence of post-development discourse also to some extent gives reflection on what is development all about. People in so-called developed countries also are in endless quest for more social justice, for more meaning of life, for a spiritual search, creating an economy which is more caring, a technology which is not destructive for humanity. They are dealing with what they call as paradox of progress (Bregman, 2017). Here, actually, it lays the opportunity for Muslim scholars to come up with their own discourse on development for the development of the Muslim World. Discourse on Islamic-based development is actually a positive step to be enhanced further. It should benefit from both the positive side of developed countries that may have shared values with Islam and the shortcoming on the experience of what is missing from the developed countries today, not only from Muslim perspective but also from their own people perspective, so this Islamic-based development discourse will have something to offer to the global community. This indeed will require a great intellectual effort, more research, but it will be worth the effort in the quest to revive again Islamic intellectual traditions in the present era. More than that, it is an effort to put into practice the essence of Islam as a mercy for all the worlds.

\section{References}

Ahmad, K. (1981). Economic Development in an Islamic Framework. In Ahmad, K., Studies in Islamic Economics. Jeddah, Saudi Arabia \& Leicester, UK: International Centre for Research in Islamic Economics King Abdul Aziz University \& The Islamic Foundation.

Alwyni, F. A. (2011). The Islamic Paradigm on Finance, Economics, and Development. Islamic Finance News, $1^{\text {st }}$ June 2011, 27-28.

Askari, H. \& Rehman, S. (2013). A Survey of the Economic Development of OIC Countries. In Iqbal, Z. \& Mirakhor, A., Economic Development and Islamic Finance. Washington DC: The World Bank.

Bregman, R. (2017, 12 April). A growing number of people think that their job is useless. Time to rethink the meaning of work. Retrieved from https://www.weforum.org/agenda/2017/04/why-its-time-to-rethink-the-meaning-ofwork/.

Desai, R. (2009). Theories of Development. In Haslam, P.A., Schafer, J., \& Beaudet, P., Introduction to International Development: Approaches, Actors, and Issues. Ontario, Canada: Oxford University Press.

Caldentey, E. P. (2008). The Concept and Evolution of the Developmental State. International Journal of Political Economy, 37:3, 27-53.

Chapra, M. U. (2008). The Islamic Vision of Development in the Light of Maqāsid al-Sharīah. Occasional Paper Series 15. London, UK \& Virginia: The International Institute of Islamic Thought.

Engel, S. N. (2010). Development economics: from classical to critical analysis. In R. A. Denemark (Eds.), The International Studies Encyclopedia Volume II (pp. 874-892). West Sussex: Blackwell Publishing. Retrieved from http://ro.uow.edu.au/artspapers/1084/ (Faculty of Arts - Papers: University of Wollongong Australia [Research Online]) on 23 March 2017. Th

Fritz, V. \& Menocal A. R. (2006). (Re) building Developmental States: From Theory to Practice. Working Paper 274. London, UK: Overseas Development Institute.

Hettne, B. (2001). Discourses on Peace \& Development. Progress in Development Studies, 1:21, 21-36.

Hettne, B. (2005). Discourses on development. In Hayness, J. (Ed.), Palgrave Advances in Development Studies (pp. 26-46). London, UK: Palgrave Macmillan.

Islamic Development Bank. (2017). Key Development Indicators for the IDB Member Countries (Statistical Yearbook No. 37). Jeddah, Kingdom of Saudi Arabia: Islamic Development Bank.

Jolly, R., Emmerij, L., Ghai, D., \& Lapeyre, F. (2004). UN Contributions to Development Thinking \& Practice. Bloomington \& Indianapolis: Indiana University Press. 
Organization for Economic Cooperation \& Development. (n.d.). Members and partners. Retrieved from www.oecd.org/about/membersandpartners/.

Rist, G. (2010). Development as a buzzword. In Cornwall, A. \& Eade, D. (Eds.), Deconstructing Development Discourse: Buzzwords \& Fuzzwords (pp. 22-27). Warwickshire, UK \& Oxford, UK: Practical Action Publishing \& Oxfam GB.

Rostow, W. W. (1960). The Stages of Economic Growth: A Non-Communist Manifesto. Cambridge: Cambridge University Press.

Schafer, R., Haslam, P.A., \& Beaudet, P. (2009). Meaning, Measurement, and Morality in International Development. In Haslam, P.A., Schafer, J., \& Beaudet, P. (Eds.), Introduction to International Development: Approaches, Actors, and Issues. Ontario, Canada: Oxford University Press.

Salleh, M. S. (2003). 7 Prinsip Pembangunan Berteraskan Islam. Kuala Lumpur, Malaysia: Zebra Editions Sdn. Bhd.

Salleh, M. S. (2010, January). [Review of the book The Islamic Vision of Development in the Light of Maqassid alSharīah, by Chapra, M. U.J. Islamic Economic Studies, 17:2, 93:101.

Salleh, M. S. (2013). Philosophical Foundations of Islamic Development: Khurshid's Ahmad Conception Revisited. International Journal of Education and Research, 1:7, 1-16.

Todaro, M. P. \& Smith, S. C. (2011). Economic Development (1 $1^{\text {th }}$ edition). Essex, England: Pearson Education Limited.

United Nations. (2017). World Economic Situation \& Prospects. New York: United Nations.

Uvin, P. (2010). From the right to development to the rights-based approach: how 'human rights' entered development. In Cornwall, A. \& Eade, D. (Eds.), Deconstructing Development Discourse: Buzzwords \& Fuzzwords (pp. 163-174). Warwickshire, UK \& Oxford, UK: Practical Action Publishing \& Oxfam GB.

World Bank. (2016, July). World Bank Ranking List of Economies. Washington DC: World Bank.

World Bank. (2017, December 15). Gross Domestic Product 2016 (World Development Indicators Database). Washington DC: World Bank.

Ziai, A. (2007). Development discourse and its critics. In Ziai, A. (Ed.), Exploring Post-development: Theory \& practice, problems \& perspectives (pp. 3-17). London, UK: Routledge. 